\title{
Local knowledge in rubber (Hevea brasiliensis) farming systems in Sri Lanka: Applications and constraints
}

\author{
A M W K Senevirathna*, P D Pathirana*, V H L Rodrigo* and F L Sinclair** \\ * Rubber Research Institute of Sri Lanka, Dartonfield, Agalawatta, Sri Lanka \\ ** School of Environmental and Natural Resources, Bangor University, LL57 2UW, United \\ Kingdom
}

Received 20 July 2010; Accepted 03 August 2010

\begin{abstract}
To explore the local knowledge intermingled with rubber farming systems in Sri Lanka and to compare the knowledge of traditional (TRA) and non-traditional (NTRA) rubber growing areas in Sri Lanka, a knowledge base (KB) was developed acquiring farmers' knowledge from the above two areas. For the generalisation of the $K B$, a non-leading questionnaire based survey was done island wide in all rubber growing regions.

Farmers in TRA have detailed knowledge about rubber cultivation than those who are in NTRA. However, the knowledge on intercrops, their selections, practices and interactions with the environment are better in NTRA compared to those in TRA. The main areas of knowledge were the growth and yield performance of rubber and intercrops, shade cast by rubber, soil erosion, moisture and fertility. Application of 'clay mixture' on the bark of the rubber tree to prevent bark from diseases and to enhance the growth of the bark and avoiding the period from defoliation to refoliation from harvesting of rubber latex ('winter resting') were outstanding among the practices of farmers done on their knowledge which are to be investigated scientifically.
\end{abstract}

Key words: farmer knowledge, farming systems, intercropping, knowledge base, nontraditional area, traditional area, WinAKT

\section{Introduction}

Locally derived understanding about agriculture and environment, based on experience and real world observation is commonly referred to as "local knowledge" (Sinclair \& Joshi, 2000). Farming systems such as slash and burn agriculture; farming staple food crops and the extraction of renewable resources from forests may involve local knowledge to a significant extent (Lawrence, 2000). Local knowledge has been used in some development projects but it is often under utilised even in participatory development thus their 
knowledge may remain implicit (Sinclair \& Walker, 1999).

With the development of agricultural technology, many recommendations from scientific research have crept into farmers' practise. This has led to the rapid displacement of traditional farming practices and the loss of local knowledge (Gliessman et al., 1981). However, in some parts of the world, farmers' local knowledge still plays an important role in their agricultural practices (Thapa et al., 1997). In contrast, with smallholder plantation tree crops such as rubber (Hevea brasiliensis), introduced to Sri Lanka over a century ago in the colonial era, there has been a strong influence of government schemes and extension advice. It can be expected that locally derived knowledge and practice about rubber growing will be intermingled with the conventional agricultural techniques and recommendations that have been associated with the promotion of rubber in the country.

In Sri Lanka, farmers' knowledge on one of the important traditional agroforestry practices, 'Kandyan Forest Gardens' (Hitinayake, 1996) and rice cultivation (Wettasinha, 1997) have been well documented. However, no such studies were found on plantation crops such as rubber, perhaps because establishment and management of these crops have tended to be based on recommendations from the relevant research institutes. However, in other rubber growing countries, for example Indonesia, where there is a tradition of farmers growing rubber on their own accord (Salafsky, 1994) there have been studies of local knowledge. It is evident from these that farmers use their knowledge to improve rubber cultivation (Dove, 1994).

The decision taken to establish the Smallholding Department in the Rubber Research Institute of Sri Lanka (RRISL) in 1935 indicates that there were considerable amount of smallholders before. Therefore, they can be expected to have experience and knowledge on agronomic practices and latex exploitation. Specifically, mixed cropping with rubber has a long history in Sri Lanka. In 1905, 29 years after rubber was introduced to the country, 7,256 acres of rubber/tea intercropping were recorded (Lock, 1913). However, the implementation of the rubber replanting subsidy scheme in 1953 (Pieris, 1954), which aimed to expand rubber cultivation and make rubber lands more productive, discouraged intercropping with rubber other than with ground cover crops for soil conservation. This was reversed when the government encouraged food production in 1973 (Jayasuriya, 1977) and intercropping was recommended by the RRISL in 1979 (Chandrasekara, 1979); however, intercropping of some cash crops was recorded before this recommendation was put forward (Jayasuriya, 1977). This indicates that farmers had begun to practise intercropping with rubber, based on their own knowledge even before intercropping with rubber was officially 
recommended. Therefore, a study of farmers' knowledge on intercropping as well as on rubber cultivation is important to inform the development of research strategies.

In Sri Lanka, mixed cropping with rubber, rather than monocropping is popular among smallholder farmers (Rodrigo et al., 2001a) but not on larger plantations. Farmers plant a range of seasonal, short-term and long-term crops in rubber lands especially in the non-traditional compared to the traditional rubber growing areas while rubber remains the permanent crop in the system (Rodrigo et al., 2001b). It is reasonable, therefore, to assume that farmers have developed an understanding of crop characteristics such as seasonality and yield performance, and how they are affected by land characteristics and that they use this knowledge when integrating other crops into rubber cultivation as well as growing and exploiting the rubber itself. The present research was carried out to explore this overall hypothesis, and to investigate whether there were differences in knowledge associated with farmers' direct experience of rubber farming systems.

\section{Materials and Methods \\ Study areas and selection of informants}

Two agro-climatic zones, Low country Wet (WL) and Intermediate (IL) where rubber is grown traditionally (traditional areas-TRA) and non-traditionally (nontraditional areas-NTRA) in Sri Lanka were selected for the study. In the traditional area, rubber has been grown for more than a century, whilst rubber is a comparatively new plantation crop to the smallholder farmers in the nontraditional area ( $c a .25$ years). From each area, farmers in two districts that were known to have active (Kegalle and Moneragala) and relatively less active (Kalutara and Hambantota) extension services were selected as shown in the Figure 1.

The initial plan was to purposively select five farmers as key informants from each of a number of strata defined by their experience of intercropping and their location (Walker and Sinclair, 1998) who were practising intercropping with rubber and five who were not, from each of the four districts selected. However, it was hard to find non-intercroppers in the NTRA, as they had nearly all grown at least a single seasonal crop on their rubber lands.

To find suitable farmers, help was sought from the responsible rubber development officer (RDO), employed by the Sri Lankan Rubber Development Department (RDD). Intercroppers and non-intercroppers were selected from the villages 'Wegantale' and 'Ambulugala' from Kegalle, and 'Karannagoda', 'Kobawaka' and 'Deeyakaduwa' from Kalutara in the TRA. Informants were selected from the village 'Bookendayaya' in Hambantota and from 'Pallekiruwa' and 'Mediriya' in Moneragala in the NTRA. The total number of informants was 31 . 


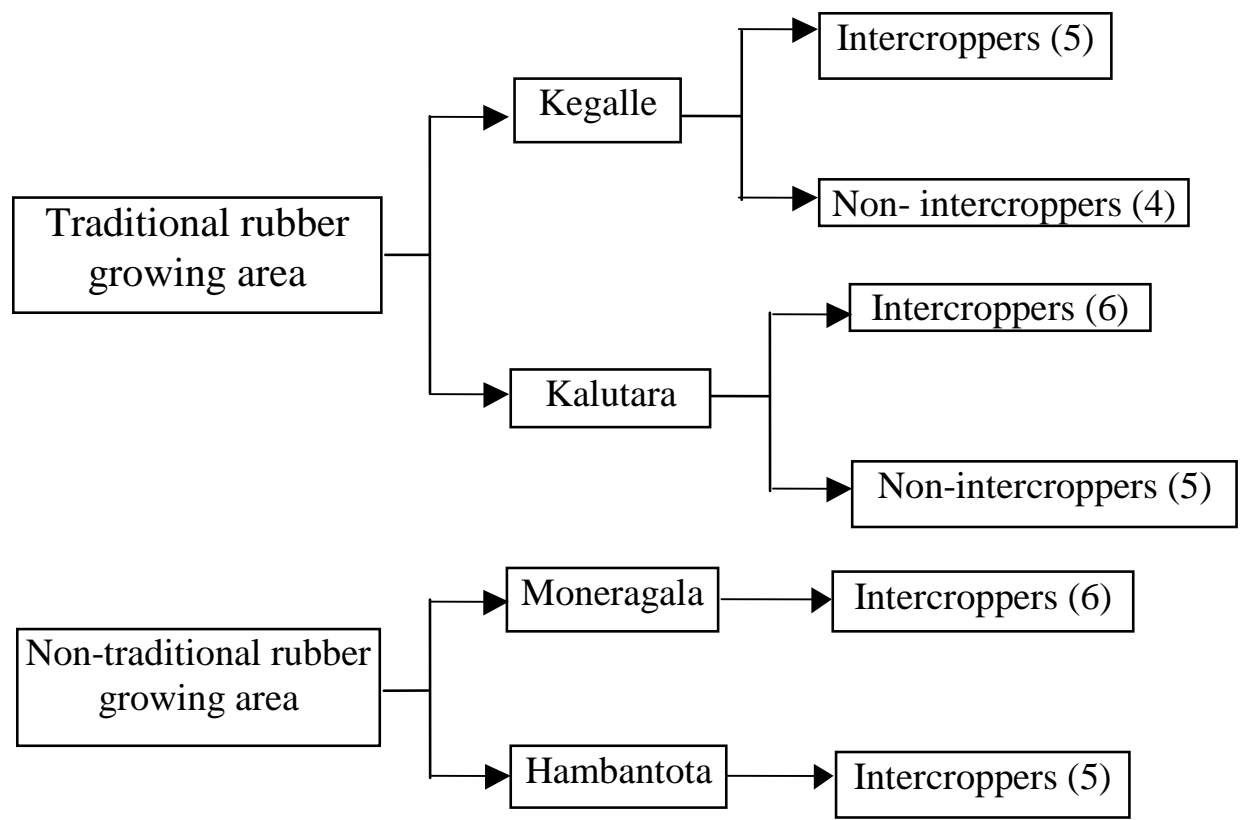

Fig. 1. Sampling scheme of key informants used for acquisition of knowledge about rubber farming in Sri Lanka. Numbers in parentheses indicate the number of farmers interviewed

\section{Acquisition of knowledge}

Semi structured interviews of key informants were used to gather farmers' local knowledge on rubber farming practices in Sri Lanka (Walker and Sinclair, 1998). A checklist covering the knowledge of rubber clones, soil and fertiliser application, soil conservation, resource capture (light, water, nutrients) by crops, rubber intercropping and sources of knowledge relating to rubber, was developed and used to guide interviews. Selected farmers were interviewed with non-leading questions using the checklist as a guide, but the interviews were allowed to deviate from the checklist in response to the farmers' interests, in order to acquire as much of their knowledge as possible. Every farmer was interviewed three times with a six-month gap between interviews. The first round of interviews was focused on the farmers' understanding generally, and the conversations ranged from 30 to 60 minutes depending on the interest of the farmer. Clarification and resolving conflicts was done in the second and third rounds, while limiting 
conversations from 30 to 45 minutes. All the interviews were recorded using a portable tape-recorder and notes were made on important points. Farmers were interviewed on their own land, allowing visual observation of their farming practices and reference to them during the interview.

\section{Representation of knowledge}

For the purpose of analysing the knowledge thus collected, the WinAKT software was used (Dixon et al., 1999). In order to put the knowledge into the programme, the recorded conversations were first transcribed. The knowledge was then broken down into unitary statements. The unitary statement is the smallest useful unit of knowledge that cannot be broken down into further unitary statements (Sinclair and Walker, 1998). These were then converted into formal statements using a restricted syntax embedded in the programme (Walker and Sinclair, 1998). Table 1 shows some examples of unitary statements and their formal representation. The source (or multiple sources) of each statement was recorded and local taxonomies of terms were represented as hierarchies of objects in which something lower in the hierarchy, such as 'rubber trees' was defined as a type of' its parent node, such as 'plants'. The knowledge base was organised as series of 'topics' defined as those statements containing particular sets of terms (Sinclair and Walker, 1998).

Table 1. Examples of unitary statements in the knowledge base on rubber farming in Sri Lanka. "Causes2way" denotes the reversibility of the causal mechanism, that is that as well as a decrease in soil fertility reducing rubber growth an increase in fertility would increase rubber growth - for some relationships this does not apply (time for example is unidirectional so things can get older but not younger), in which case the relationship is represented as "causes 1way"

\begin{tabular}{lll}
\hline $\begin{array}{l}\text { Type of } \\
\text { statement }\end{array}$ & Natural language & Formal language \\
\hline Attribute/Value & the fertility of black-soil is high & att_value (black_soil,fertility,high) \\
Causal & $\begin{array}{l}\text { a decrease in fertility of soil causes } \\
\text { a decrease in rate of rubber growth }\end{array}$ & $\begin{array}{l}\text { att_value (soil,fertility,decrease) } \\
\text { causes2way att_value (process } \\
\text { (rubber,growth),rate,decrease) }\end{array}$ \\
Comparison & $\begin{array}{l}\text { Comparison (root_depth, } \\
\text { the root-depth of rubber is greater } \\
\text { than banana }\end{array}$ & $\begin{array}{l}\text { rubber,greater_than,banana) } \\
\text { Link (contains,clay_mixture,clay) }\end{array}$ \\
& clay mixture contains clay &
\end{tabular}


According to the information gathered from farmers, a main knowledge base (KB) was developed. After completion of the main $\mathrm{KB}$, major subject areas of knowledge on: rubber growth and yield, banana (Musa sp.) growth, shade, soil erosion, soil fertility and soil moisture were identified. Further topics were made according to the location and categories of farmers that were shown in the Figure 1 to facilitate comparison of knowledge amongst different groups of farmers. From the main KB, two sub KBs: 'TRA' and 'NTRA' were created comprising the statements from the topics described above.

\section{Knowledge analysis}

Analyses of the major areas of knowledge among the sub KBs was done using the system tools. These are automated reasoning tools that allow comparative analysis of different sets of knowledge and can be customised to suit user requirements. Similarities, differences and unique knowledge on the major subject areas amongst farmers of the TRA and NTRA in Sri Lanka were analysed.

\section{Generalisation}

In order to test the validity of the knowledge acquired from the small purposive sample of key informants, in terms of the wider community of smallholder rubber farmers, and to investigate distribution of knowledge amongst people, a questionnaire-based survey derived from the $\mathrm{KB}$ was administered across a range of rubber growing districts in Sri Lanka as described by Walker and Sinclair (1998). The questionnaire concentrated on the major areas of knowledge in the main KB: soil erosion, soil fertility, soil moisture and shade. The questionnaire comprised a series of non-leading questions and was pre-tested among a random sample of farmers after which some adjustments were made prior to its use in the survey.

A stratified sample of 139 rubber farmers under the same categories as for the original knowledge acquisition, intercroppers and non-intercroppers, from the TRA and NTRA were used. In addition to the places used in the previous knowledge acquisition, Ratnapura, Galle/Matara and Colombo/Gampaha districts from the TRA were also selected but Moneragala and Hambantota are the only districts in the NTRA where the survey was conducted. From each place, 20 farmers were randomly selected, so that they included both intercroppers and nonintercroppers, in proportion to their frequency in the selected villages. The villages and the farmers used for the previous knowledge acquisition were excluded from this survey. Enumerators from the University of Sri Jayawardhanapura, Sri Lanka carried out the survey, which was combined with a social livelihood survey on farming systems in Sri Lanka. From the questionnaire, statements from 'A1' to 'F2' mentioned in Table 2 were made on the farmers' articulated knowledge based on the non-leading questions and 
used for the generalisation of farmers' knowledge. Data were analysed using Chi-square test (SAS Institute Inc., Cary, NC, USA).

\section{Results}

The knowledge base created on rubber farming in Sri Lanka consisted of a total of 241 statements (including 200 causal, 22 comparison, 14 attribute and 5 link statements - see Table 1) derived from 31 informants. The major areas of knowledge identified were related to the topics: rubber growth and yield, banana growth, shade, soil erosion, soil fertility and soil moisture. From the main KB, two sub KBs, 'TRA' and 'NTRA' were created. Some differences as well as similarities of knowledge among the groups of farmers were identified in the main areas of knowledge acquired, as described in this section.

\section{Knowledge on growth and yield of rubber}

Farmers in the TRA have a more detailed knowledge of the growth of rubber than farmers in the NTRA. TRA farmers explained the factors affecting the growth of rubber elaborately. For example, soil types, types of fertiliser and their rates of application, how rubber affects the planting of other crops and the effects of rubber shade on intercrops such as banana, cinnamon, passion fruit and leguminous cover crops (Fig. 2). Farmers in the TRA were equipped with knowledge about some characteristics of different rubber clones too. Another practice is that some of the
TRA farmers apply a mixture of clay, cow dung and sulphur ('Clay mixtute') on the tapping panel of rubber (from where the latex is exploited) to enhance the growth of the bark and to prevent bark diseases during the resting period (from defoliation during winter to completion of refoliation).

Knowledge of latex yield of rubber was restricted to the TRA as rubber in the NTRA was too young for farmers to have had much experience of rubber tapping and yield. Farmers in the TRA, in contrast, had a vast experience of exploiting rubber. The rate of fertiliser application and increasing rubber tree crown density caused increase in latex yield. When rubber flowered ('development stage') latex yield decreased while during the seed dispersal, latex yield was high. Farmers tapping skill also affected the yield of latex and skilled tappers could get higher yields than less experienced farmers. The natural defoliation of rubber ('wintering') resulted in low latex yield during the wintering period. Farmers in the TRA compared the yield of different rubber clones they had grown.

\section{Knowledge on growth of banana}

The factors affecting banana growth were elaborated more extensively by the intercroppers than non-intercroppers, presumably because of their experience in intercropping banana with rubber. Soil fertility related factors (application of fertiliser, inherent soil fertility, soil colour and texture, application of 
organic matter and soil moisture), planting density of banana and effects of rubber shading on the growth of banana were highlighted by them (Fig.
2). Non-intercroppers did not offer explanations about banana growth with rubber.

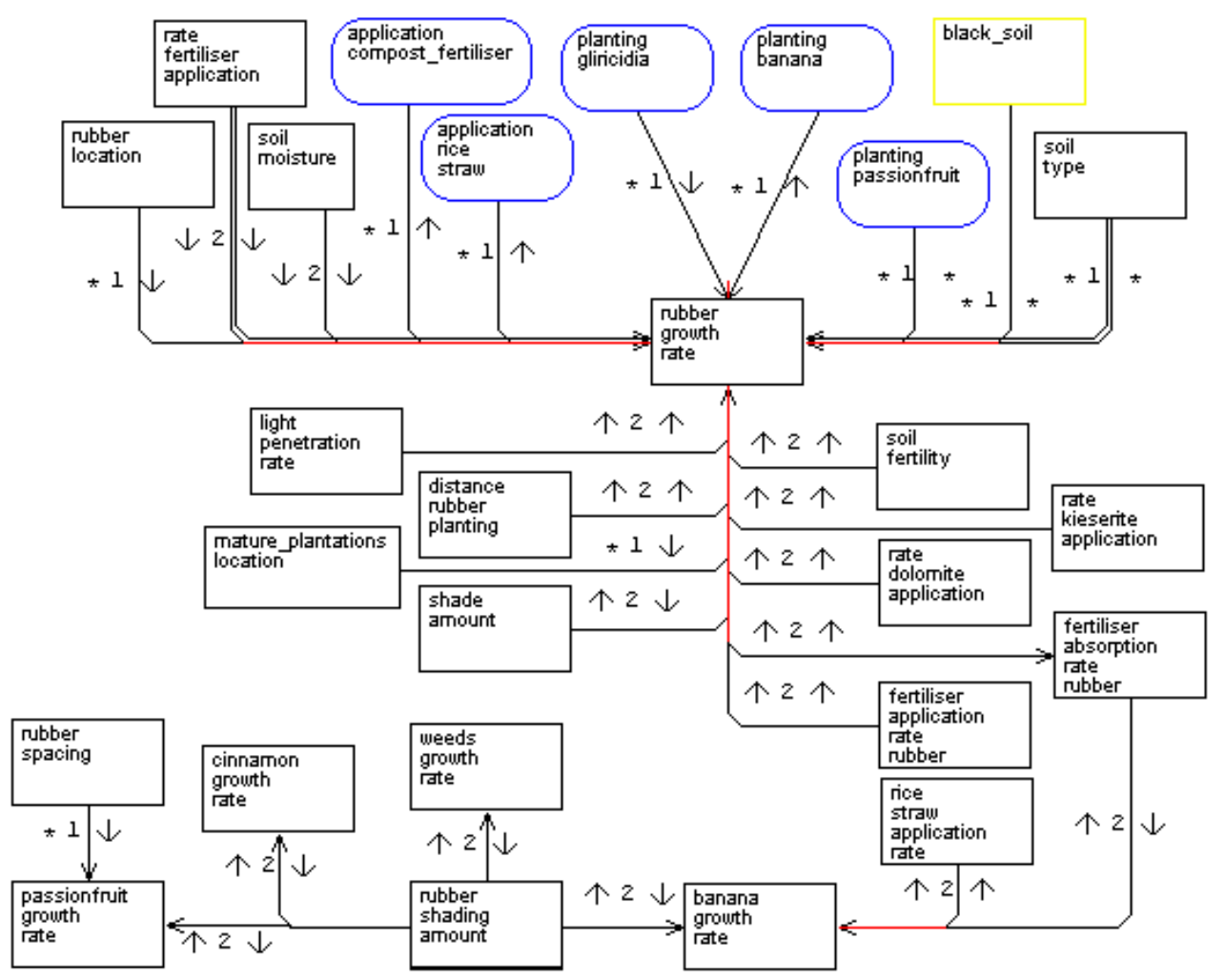

Fig. 2. A systematic representation on causal knowledge about rubber growth. Nodes with sharp corners and with blunt corners represent attributes and actions involved respectively. The direction of the arrow, which connects two nodes, indicates the direction of the causal influence. Upward and downward small arrows at the sides of the numeral indicate an increase or decrease in the causal or effect nodes respectively; whilst an asterisk (*) indicates anything other than increase or decrease (e.g. high or low) that is specified in the knowledge base. The numeral is used to describe whether the cause is one-way (1) or two-way (2) as explained in the legend to Table 1. 
The knowledge of farmers in the TRA was similar to that of intercroppers, whilst the understanding of farmers in the NTRA about banana growth was much less. Application of rice straw, loosening of soil to improve root growth were important from the farmers' point of view to enhance the growth of banana.

\section{Knowledge about shade}

Shade effects were extensively elaborated by intercroppers, more specifically the effect of shade from rubber on crops such as banana (Musa sp.), cinnamon (Cinamomum sp.), passion fruit (Passiflora) and Citronella $s p$. (known locally as 'pangiri'). Nonintercroppers had knowledge of effects of rubber shade on leguminous cover crops and on tea, and conversely effects of plants in live fences ('boundary plants') on growth of rubber (Fig. 2).

According to farmers in both TRA and NTRA, growth of banana was affected by rubber shade; but there was more explanatory detail evident from farmers in the TRA (Fig. 2). TRA farmers also mentioned that cinnamon and passion fruit were affected by rubber shade (Fig. 2 ). The majority of farmers said that after three to five years of rubber growth, the growth and yield of almost all intercrops were affected by rubber shade.

\section{Knowledge about soil erosion}

Planting cover crops and the establishment of drains and terraces as soil conservation measures were pointed out by both intercroppers and non-intercroppers. The cover crops that are grown on rubber lands are mainly Pueraria phaseoloides and Calopogonium muconoides. Farmers do not distinguish between these species and refer to them both locally as 'awarana waga' or 'pohorawel'. In addition, intercroppers have knowledge of how cultivation of other crops, which are mainly those used as intercrops in rubber lands, affect soil erosion. Harvesting cassava and groundnut and clearing and burning of weeds aggravate soil erosion whilst planting of Citronella sp. ('pangiri') reduces soil erosion although it causes low soil fertility when grown continuously on the same land.

\section{Knowledge about soil fertility}

According to intercroppers, application of Gliricidia leaves, weed litter, Crotolaria micans (locally known as 'andanaheeriya') litter, decaying Citronella leaves and abandoning of the land for a period without cropping were means of enhancing soil fertility; whilst soil erosion and continuous cropping with Citronella or millet (Eleusine indica) caused a reduction in soil fertility. Soil fertility in turn affected the growth of rubber and banana and yield of all crops. In contrast, non-intercroppers' knowledge about soil fertility was limited and according to them, planting cover crops and application of weed litter affected soil fertility positively. Knowledge about soil fertility was more explanatory 
amongst farmers in the NTRA than the TRA as they used a number of seasonal crops and practised crop rotation.

\section{Knowledge about soil moisture}

Farmers said that planting cover crops and banana and application of weed litter and banana trash on soil increases soil moisture and that improved soil moisture increases growth of a number of crops. Majority of the farmers were of the view that the presence of banana plants leads to higher soil moisture, which in turn enhances growth of rubber.

\section{Knowledge generalisation}

Table 2, Figures 3 and 4 summarise the validation of knowledge acquired and presented in the knowledge base of rubber farming in Sri Lanka. On the issue of soil erosion, sloping lands (A1) were most frequently cited as a cause of soil erosion than soil looseness (A2) or clear weeding (A3), irrespective of the TRA or NTRA (Fig. 3, 4). Most of the farmers establish drains (B1) or terraces (B2) as the remedy for soil erosion whilst a very few farmers mentioned the importance of the cover crops (B3) in controlling soil erosion. Although, farmers in the TRA considered drains (B1) as a remedy for soil erosion, NTRA farmers did not $(p<0.01)$. More than half the farmers $(56 \%)$ from the NTRA mentioned that the planting of banana increases soil moisture (C1) whereas fewer TRA farmers cited banana as affecting soil moisture $(p<0.01)$. Almost half the TRA farmers which was over twice the percentage of the NTRA farmers said that cover crops increased soil moisture $(\mathrm{C} 2, p<0.01)$. Majority of the farmers, $75 \%$ overall, mentioned that soil fertility affected the growth of rubber (D1). Fewer number of both TRA and NTRA farmers mentioned that soil fertility affect the growth of banana (D2). However, there were differences in the frequency with which farmers in different groups cited banana as a cause of increased soil fertility (E1). While over half of the NTRA farmers said this, less than $10 \%$ of the TRA farmers said $(p<0.01)$. Knowledge about the effects of cover crops (E2) and mulching (E3) on soil fertility were different amongst the regions (Fig. 4) and the proportion of the NTRA farmers who mentioned mulching $(41 \%)$ was double the proportion of the TRA farmers who mentioned this $(p<0.05)$. Of the farmers taking part in the survey, $8 \%$ and $22 \%$ farmers respectively said that rubber shade caused an increase (F1) and decrease $(\mathrm{F} 2)$ in the growth of other crops (data not shown); but there were marked differences amongst groups. Virtually no TRA farmers mentioned rubber shade as positive for crop growth whereas almost a quarter of the NTRA farmers did so. Similar proportions, about a fifth, of NTRA and TRA farmers said that rubber shade decreased growth of other crops. 
Table 2. Summary of post-survey coding of answers from the non-leading questions of the main areas of knowledge as described in 'generalisation of knowledge' and used for the Figure 3 (e.g. A2 - soil erosion is increased by soil looseness)

\begin{tabular}{lllll}
\hline & & $\mathbf{1}$ & $\mathbf{2}$ & $\mathbf{3}$ \\
\hline A & Soil erosion is increased by & sloping lands & soil looseness & clearing weeds \\
B & Soil erosion is decreased by & drains & terraces & cover crops \\
C & Soil moisture is increased by & banana & cover crops & \\
D & Soil fertility affects & rubber growth & banana growth & all crops \\
E & Soil fertility is increased by & banana & cover crops & mulching \\
F & Rubber shade on crops & increase & decrease & \\
& growth & & & \\
\hline
\end{tabular}

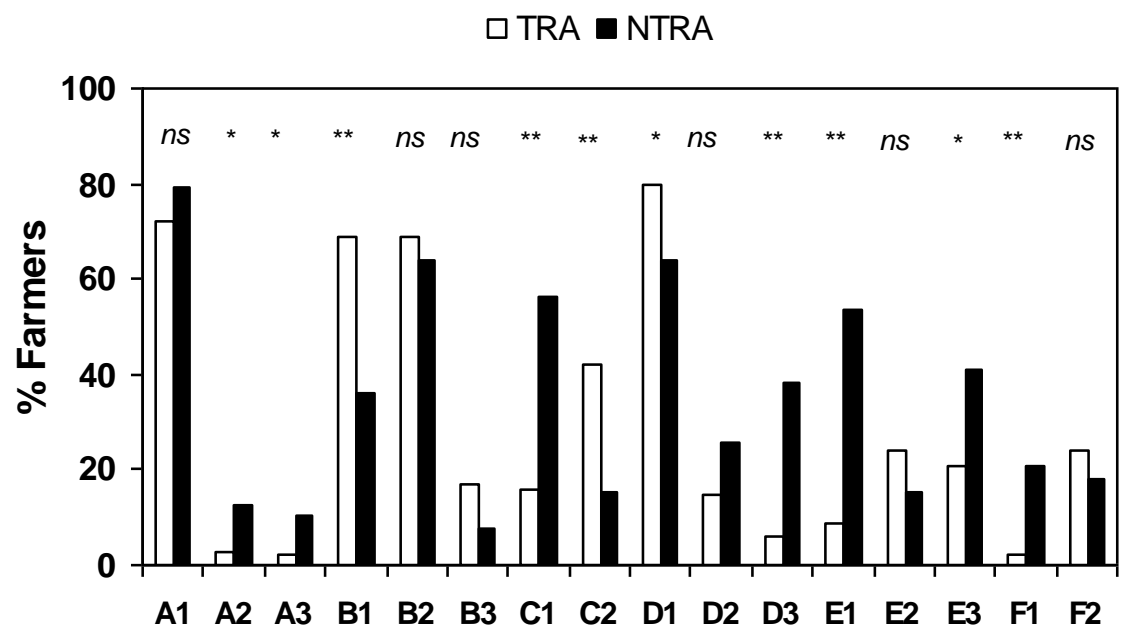

Fig. 3. Percentage of farmers articulating items of knowledge, A1 to F2 (Table 2) in the Traditional (TRA) and non-traditional (NTRA) rubber growing areas in Sri Lanka. One and two asterisks indicate respectively the significant levels of $p \leq 0.05$ and $p \leq 0.01$ while $n s$ indicates that the response is not significant between the two groups. Data are from interviews with 139 rubber farmers from seven rubber growing regions in Sri Lanka

\section{Discussion}

Although rubber has been one of the most important crops for the economy of the smallholder farmers in the TRA for more than a century, it is relatively a new crop to farmers in the NTRA. Therefore, the knowledge of agronomic practices and exploitation of rubber is more detailed amongst farmers in the TRA than in the NTRA. 

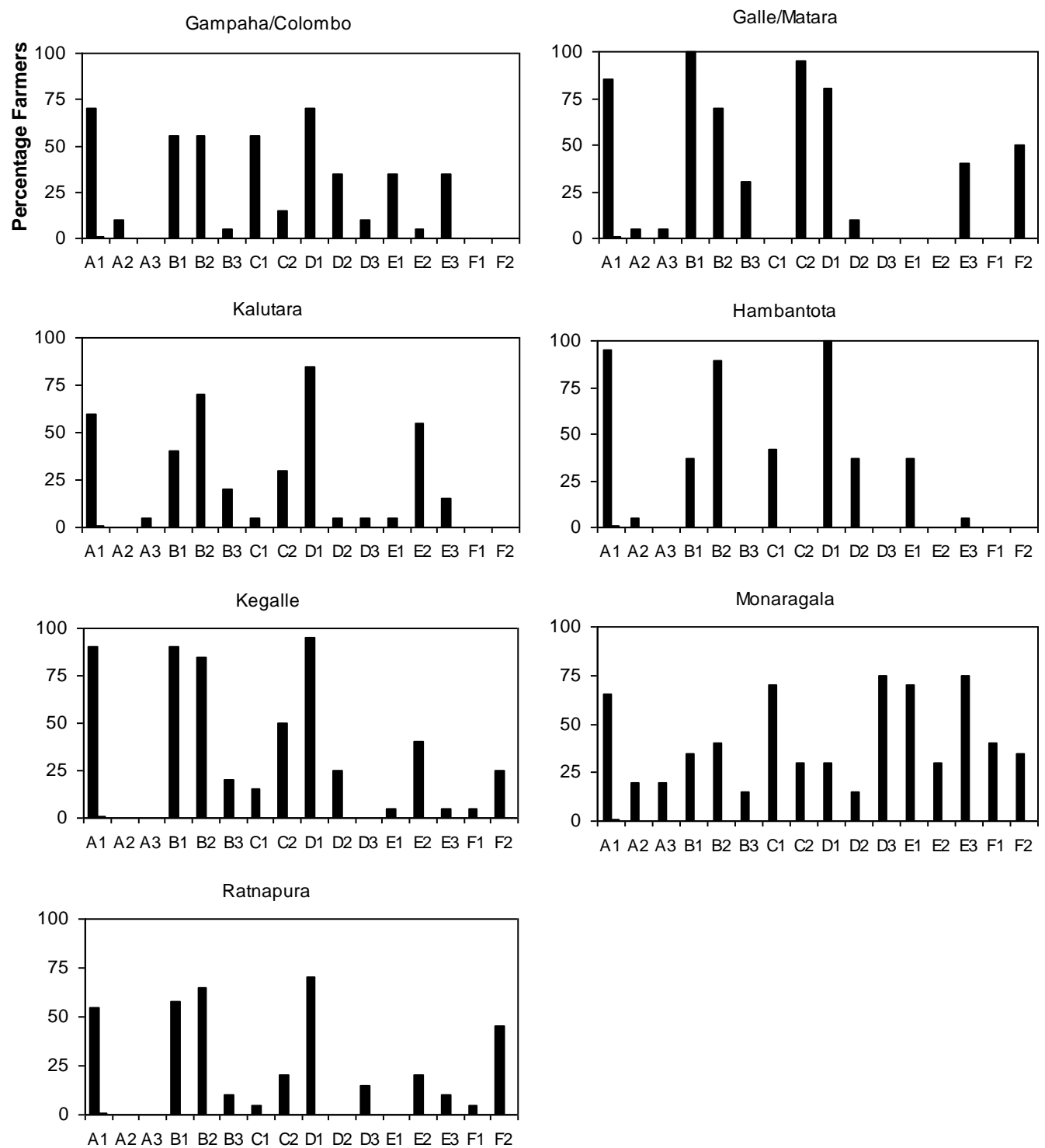

Fig. 4. Percentage of farmers articulating items of knowledge, $A 1$ to $F 2$ (Table 2) in seven rubber growing areas in Sri Lanka (Gampaha/Colombo, Kalutara, Kegalle, Ratnapura, Galle/Matara from the traditional area and Moneragala, Hambantota from the nontraditional area). Data are from interviews with 139 rubber farmers in these seven region 


\section{Rubber exploitation and latex yield}

Rubber in most of the smallholdings in the NTRA is young and, therefore, it is not surprising that understanding of the methods of exploitation and yield is limited among the NTRA farmers. By contrast, from their long experience, TRA farmers have knowledge of identification, yield performance and susceptibility to diseases of different rubber clones such as PB 86 and RRIC 100. TRA farmers compared these two clones in terms of growth and susceptibility to leaf and bark diseases. Clone PB 86 has been found to be more susceptible to diseases than RRIC 100 (Jayasinghe, 2001) which is opponent to the farmers' knowledge. All the farmers who made this statement were from the same village in the wet zone, and so they might have experienced a period of continuous wet weather causing the bark rot. Although it is recommended that the tapping operation is carried out every other day for clones recommended and not during wet weather, farmers generally practise daily tapping and there is high possibility of opening the tapping panel during wet weather. In order to prevent bark diseases and to improve bark growth, some of the TRA farmers apply a mixture of clay, cow dung and sulphur on the tapping panel especially during the defoliation period. This is not a recommendation by the RRISL, but a farmer practice, developed from their experience, which deserves further investigation as to its effectiveness. During the period between defoliation and refoliation, smallholder farmers stop exploitation for a period of about one month (this is known as 'winter resting'). This has been a common practice in the smallholder sector but not in the estate sector where the income loss during this period was considered to outweigh the benefit of resting. Farmers believe that exploitation of latex during this period may weaken the plant and also that resting the plant during this period will cause an increase in yield in subsequent tapping. Increased latex yield following winter resting and a decrease in foliar nutrients due to continuous tapping during refoliation have been scientifically observed and reported (Jayakody, 1996) in support of the farmers' understanding. However, an economic analysis on winter resting and continuous tapping is required in order to evaluate the economic viability of winter resting. Farmers in the TRA also know that the latex yield is high after refoliation, and low during defoliation, flowering and fruit setting. Nutrient compensation for reproduction might lead to low latex yield during flowering and fruit set, and increased latex production as a result of increased leaf area after refoliation seems likely.

\section{Rubber intercropping}

Intercroppers showed more detailed understanding than non-intercroppers of cultivation of other crops with rubber. Of all the intercrops, knowledge of planting banana was the most explanatory which is commensurate 
with banana being the most common companion crop in rubber smallholdings in the country with about $80 \%$ of intercroppers using banana (Rodrigo et al., 2001a). Most of the intercroppers prefer to plant single or double rows of banana between two rows of rubber (space between rows is $8.1 \mathrm{~m}$ ), because farmers suspect that three rows of banana may affect growth and yield of both crops. From the on-farm research on different densities of banana, it was clear that three rows of banana between the rows of rubber did not affect detrimentally the growth of either crop even without application of fertiliser to banana (Senevirathna, 2001). According to farmers' observations, planting banana is important for enhancing soil moisture and fertility in addition to the yield benefits. This was mainly highlighted by intercroppers and the farmers in the NTRA (Figs. $3 \& 4$ ). Farmers in the NTRA have a detailed understanding of the effects of crops on the micro-environment of other crops as their farming systems consist mainly of mixed cropping.

Shade by rubber affecting intercrops after three to five years of rubber growth is one of the major issues faced by farmers with respect to integrating other crops with rubber. Growth and yield of intercrops such as, banana, cinnamon, passion fruit and ground cover crops were reduced because of shade of rubber according to farmers' experience (Fig. 2). In support of this, a number of authors have observed the reduced growth and yield of banana, papaya (Ibrahim, 1991), mungbeans, soybeans, groundnut and maize with canopy development (Laosuwan et al., 1987) when intercropped with rubber. Furthermore, reduced photosynthetic productivity of both rubber and banana was observed as an effect of intense shade (Senevirathna et al., 2003, 2008). In order to reduce the shade imposed on intercrops, some of the farmers prune selected branches of rubber trees and plants on boundaries. This in turn increases the light incident on intercrops and encourages their growth. In contrast, mainly intercroppers and farmers in the NTRA observed increased growth of crops due to rubber shade during first two years. This might be due to the beneficial effects of mutual shading together with the beneficial microclimatic changes such as increased relative humidity, reduced soil and leaf temperature and lower evaporative demand (Korikanthimath et al., 2000).

\section{Soil fertility and erosion}

Soil erosion is a major problem for farmers irrespective of the region or the category of farmers. Farming on sloping lands is the main cause of soil erosion, and drains and terraces are the main remedies to control soil erosion (Fig. $3 \& 4$ ). In addition, ground cover crops such as Pueraria phaseoloides and Calopogonium muconoides are also grown. These ground cover crops are recommended by the RRISL for soil conservation in rubber plantations. From the generalisation survey, it is 
clear from the farmers' perspective that cover crops are more important as soil moisture and soil fertility enhancing creepers rather than for soil erosion control (Fig. $3 \& 4$ ). This is possibly due to the underestimation of the role of soil erosion control by cover crops with non-leading questions used in the survey. Soil erosion aggravates the condition of decreased soil fertility. Farmers also have knowledge about improving soil fertility by means of mulching, planting cover crops and allowing a fallow period.

\section{Utility of local knowledge about rubber in Sri Lanka}

In Sri Lanka, rubber cultivation by smallholders has been subsidised (Pieris, 1954) and, therefore, cultivation practices have been based on recommendations emanating from the extension service provided through the RRISL and RDD. Therefore, farmers' knowledge is mainly based on the knowledge gained through the extension services except a few cases where their own knowledge has been applied such as the application of 'clay mixture' to the bark to prevent bark diseases and to enhance bark growth of rubber. However, the effectiveness of this practice is unknown and testing it prior to possible extrapolation to other rubber growers is needed.

Application of farmers' knowledge in rubber cultivation in a country like Indonesia which has more than 20 times more area under rubber than Sri Lanka is associated with farmers practicing different rubber agroforestry systems rather than in response to promoted schemes. These systems include shifting cultivation of upland rice with wild rubber (Gouyon, 1993), which may become more permanent rubber than rotational where 'sisipan' is practised involving planting of seedling rubber in the gaps in mature rubber agroforests (Joshi et al., 2001). In these systems, farmers' have freedom to manipulate the system. Increasing planting density of rubber to control the growth of the weed, Imperata cylindrica has been used by the farmers in Indonesia (Penot et al., 1997). Smallholders in Sri Lanka also have a good understanding about the effects of shade cast by rubber and other crops and they reduce shade by selective pruning of branches of rubber and live fences.

In the present research, farmer interviews and the generalisation survey were carried out by asking non-leading questions. Therefore, in some areas interlinking of fragments of knowledge was difficult. In the survey, only if farmers actively mentioned something, it was recorded. This probably underestimates the number of farmers actually knowing about various practices since they may have failed to articulate knowledge that they held.

The present knowledge acquisition has revealed some interesting farmer practices that researchers were not previously focused on and has revealed a reasonable appreciation of causal mechanisms relating microclimate and agronomy. These indicate that extension 
materials could be designed to allow some flexibility for the incorporation of farmers existing knowledge. The clear differences in knowledge amongst farmers in the wet and intermediate zones, related to their previous experience of rubber growing, identify priorities for extension in the intermediate zone.

\section{Acknowledgements}

We wish to thank first the farmers involved in the research for their immense support given throughout towards the success of this project. Our thanks are extended to Dr. (Mrs.) Wasana Wijesuriya, Biometrician of the Rubber Research Institute of Sri Lanka for her great assistance in analysing data. This publication is an output from the project, R7212 of Plant Science Research Programme funded by the UK Department for International Development (DFID) for the benefit of developing countries. The views expressed are not necessarily those of DFID.

\section{References}

Chandrasekara, L B (1979). Intercropping, In: Annual Review of the Rubber Research Institute of Sri Lanka 1979, 2225.

Dixon, H J, Doores, J W, Joshi, L and Sinclair, F L (1999). Agroforestry Knowledge Toolkit for Windows (WinAKT): Methodological Guidelines, Computer Software Manual. School of Agricultural and Forest Sciences, University of Wales, Bangor, United Kingdom.
Dove, M R (1994). Transition from native forest rubbers to Hevea brasiliensis (Euphorbiaceae) among tribal smallholders in Borneo. Economic Botany 48 (4), 382-396.

Gliessman, S R, Garcia, E R and Amador, A $M$ (1981). The ecological basis for the application of traditional agricultural technology in the management of tropical agro-ecosystems, AgroEcosystems 7 (3), 173-185.

Gouyon, A (1993). The south Sumathran plains: from forests to rubber plantations, Tiers Monde 34 (135), 643670.

Hitinayake, H M G S B (1996). Farmers' knowledge and the development of complex agroforestry practices in Sri Lanka. PhD Thesis. School of Agricultural and Forest Sciences, University of Wales, Bangor, UK.

Ibrahim, A G (1991). Influence of rubber canopy on intercrop productivity, Trans. Malaysian Society of Plant Physiology 2, 75-79.

Jayakody, J A C S (1996). The effect of tapping during wintering period on yield and leaf nutrient status of rubber. $B S C$ Dissertation. University of Peradeniya, Sri Lanka.

Jayasinghe, C K (2001). Common diseases, In: Handbook of Rubber Vol. 1: Agronomy. (Tillekeratne, L M K and Nugawela, A eds.) pp. 97-113. Rubber Research Institute of Sri Lanka. Sri Lanka.

Jayasuriya, S K W (1977). The long-term investment decision: a case study of the rubber smallholders of Sri Lanka, $P h D$ Thesis. Australian National University, Australia.

Joshi, L, Sinclair, F L and van Noordwijk, M (2001). Local ecological knowledge and gap replanting in jungle rubber 
agroforests, Jambi, Indonesia, Workshop, 3-6 September 2001, Muara, Jambi, Indonesia.

Korikanthimath, V S, Ankegowda, S J, Yadukumar, N, Hegde, R and Hosmani, M M (2000). Microclimatic and photosynthetic characteristics in arecanut and cardamom mixed cropping system, Journal of Spices and Aromatic Crops 9(1), 61-63.

Laosuwan, P, Yeedum, I, Sripana, P and Sirisongkram, P A (1987). Study on intercropping of young rubber, I. Yield potential of different intercrops. Thai Journal of Agricultural Science 21(3), 179-188.

Lawrence, A ed. (2000). Forestry, Forest Users and Research: New Ways of Learning, European Tropical Forest Research Network, The Netherlands.

Lock, R H (1913). Rubber and Rubber Planting, University Press. Cambridge, UK. pp 1-13.

Penot, E, Sist, P, Sabogal, C and Byron, Y (1997). Prospects for conservation of biodiversity within productive rubber agroforestry in Indonesia. Proceedings of an International Workshop, 17-19 November 1997, Bogor, Indonesia. pp 21-32.

Pieris, W I (1954), Replanting of rubber smallholdings under the subsidy scheme, Quarterly Circulars of the Rubber Research Institute of Sri Lanka 30(1), 16-19.

Rodrigo, V H L, Stirling, C M, Narampanawa, R M A K B and Herath, P H M U (2001a). Intercropping of immature rubber in Sri Lanka: present status and financial analysis of rubber intercrops planted at three densities of banana, Agroforestry Systems 51, 35-48.

Rodrigo, V H L, Thennakoon, S and Stirling, C M (2001b). Priorities and objectives of smallholder rubber growers and the contribution of intercropping to livelihood strategies: a case study from Sri Lanka. Outlook on Agriculture 30(4), 261-266.

Salafsky, N (1994). Forest gardens in the Gunung Palung region of West Kalimantan, Indonesia defining a locally developed market oriented agroforestry system. Agroforestry Systems 28 (3), 237-268.

Senevirathna, A M W K (2001). The influence of farmer knowledge, shade and planting density on smallholder rubber/banana intercropping in Sri Lanka, PhD Thesis. University of Wales, United Kingdom.

Senevirathna, A M W K, Stirling, C M and Rodrigo, V H L (2003). Growth, photosynthetic performance and shade adaptation of rubber (Hevea brasiliensis Muell. Arg.) grown in natural shade, Tree Physiology 23, 705-712.

Senevirathna, A M W K, Stirling, C M and Rodrigo, V H L (2008). Acclimation of photosynthesis and growth of banana (Musa sp.) to natural shade in the humid tropics. Experimental Agriculture 44(3), 301-312.

Sinclair, F L and Joshi, L (2000). Taking local knowledge about trees seriously, In: Forestry, Forest Users and Research: New Ways of Learning, (Lawrence, A ed.) European Tropical Forest Research Network, The Netherlands. pp 45-61.

Sinclair, F L and Walker, D H (1998). Acquiring qualitative knowledge about complex agroecosystems, Part 1: Representation as natural language, Agricultural Systems 56 (3), 341-363.

Sinclair, F L and Walker, D H (1999). A utilitarian approach to the incorporation of local knowledge in agroforestry 
research and extension, In: Agroforestry in Sustainable Agricultural Systems, (Buck, L E Lassoie, J P and Fernandes, E C M, eds), CRC Press LLC, USA. pp 245-275.

Thapa, B, Walker, D H and Sinclair, F L (1997). Indigenous knowledge of the feeding value of tree fodder, Animal Feed Science Technology 67, 97-114.

Walker, D H and Sinclair, F L (1998). Acquiring qualitative knowledge about complex agroecosystems, Part 2: Formal representation, Agricultural Systems 56 (3), 365-386.
Wettasinha, C (1997). Moulding our own future, In: Farmers' research in practice: lessons from the field. (Veldhuizen, L V, Waters-Bayer, A, Ramirez, R, Johnson, D A and Thompson, J, eds.). Intermediate Technology Publications, UK.

Address for correspondence: Dr A M W K Senevirathna, Botanist, Rubber Research Institute of Sri Lanka, Dartonfield, Agalawatta, Sri Lanka.

e-mail: wasanthasen@gmail.com, 